Note

\title{
ACCLIMATIZATION OF MICROPROPAGATED Heliconia bihai (HELICONIACEAE) PLANTS
}

\author{
Paulo Hercílio Viegas Rodrigues ${ }^{1 *}$; Ana Maria Liner Pereira Lima²; Gláucia Maria B. \\ Ambrosano 3 ; Maria de Fátima Batista Dutra ${ }^{4}$ \\ ${ }^{1}$ UFRN/PPGGBM/BioCampo - Alameda das Mansões, 1178 - Candelária - 59067-000 - Natal, RN - Brasil. \\ ${ }^{2}$ USP/ESALQ - Depto. Produção Vegetal, C.P. 09 - 13418-900 - Piracicaba, SP - Brasil. \\ ${ }^{3}$ UNICAMP/FOP - Depto. Odontologia Social - Bioestatística - 13418-900 - Piracicaba, SP - Brasil. \\ ${ }^{4}$ UFRN/PPGGBM/BioCampo. \\ *Corresponding author <phrviegas@hotmail.com>
}

\begin{abstract}
To evaluate the behavior of micropropagated heliconia seedlings during the acclimatization process using different substrates and shade levels, seedlings of $H$. bihai (Lobster Claw I) were planted in plastic trays using the substrates: washed sand, vermiculite (medium texture), and PlantMax ${ }^{\circledR}$ Horticultura, and shade cloths with percentages of $0 \%$ (full sun), $30 \%, 40 \%, 50 \%, 60 \%, 70 \%$, and $80 \%$ of shade in relation to full sun. Best results were obtained for washed sand and PlantMax substrates at shade conditions starting from $50 \%$, especially at $70 \%$ and $80 \%$. Pre-existing roots from in vitro rootings were not functional, not presenting secondary roots, and showing root tissue necrosis. Acclimatized seedlings developed new roots. This finding suggests that this plant can be acclimatized without going through a laboratory rooting stage. Key words: Heliconia, ex vitro culture, rooting
\end{abstract}

\section{ACLIMATIZAÇ̃̃O DE MUDAS MICROPROPAGADAS DE Heliconia bihai (HELICONIACEAE)}

\begin{abstract}
RESUMO: A cultura da helicônia é a que apresenta maior crescimento entre o cultivo de flores tropicais para a exportação. Avaliou-se o comportamento de mudas de helicônias micropropagadas no processo de aclimatização, em diferentes substratos e níveis de sombreamento. Foram plantadas mudas de $H$. bihai (Lobster Claw I) em bandejas plásticas contendo os diferentes substratos: areia lavada, vermiculita (textura média) e PlantMax ${ }^{\circledR}$ Horticultura. Na avaliação de níveis de sombreamento foi utilizado o telado (sombrite), com ordem de sombreamento $0 \%$ (pleno sol), 30\%, 40\%, 50\%, 60\%, 70\% e 80\%. O desempenho foi superior nos substratos areia lavada e PlantMax ${ }^{\circledR}$ Horticultura e nas condições de sombreamento a partir de $50 \%$, em especial $70 \%$ e $80 \%$. As raízes pré-existentes, oriundas do enraizamento in vitro, mostraram-se não funcionais, sem a emissão de raízes secundárias e apresentando necrose do tecido radicular. As mudas aclimatizadas desenvolveram novas raízes, o que sugere que esta cultura pode ser aclimatizada sem que as plântulas passem pela fase de enraizamento em laboratório.

Palavras-chave: Helicônia, cultura ex vitro, enraizamento
\end{abstract}

\section{INTRODUCTION}

The tropical flower agribusiness has become prominent as an important source of hard currency for some countries, such as Colombia, Costa Rica, Honduras, Jamaica, the United States (Hawaii and Florida), Puerto Rico, Suriname, and Venezuela (Castro \& Graziano, 1997). In Brazil, the states of Rio de Janeiro, São Paulo, Santa Catarina, Pernambuco, in addition to Amazonas, Ceará, and Alagoas have carried out commercial plantings, especially of heliconias (Castro, 1995).

One of the obstacles found during attempts to multiply heliconias in vitro is a consequence of the fact that the presence of an endophytic bacterium of the spe- cies Pseudomonas solanacearum frequently occurs in organs that serve as explants (Atehortua, 1997; Dias \& Rodrigues, 2001). After this initial impediment was overcome (Dias, 2002), with the development of a micropropagation protocol for $H$. bihai using the shoot apex, the acclimatization of the produced material became a limiting factor in obtaining micropropagated seedlings. Acclimatization is an important step in micropropagation. During in vitro growth, plants develop under controlled conditions, including enclosed environments, without gaseous exchanges, with high moisture in the air, low light intensity, and the use of sugars from the medium as a source of carbon and energy (Preece \& Sutter, 1991; Sciutti \& Morini, 1993; Pospísilová et al., 
1999). Thus, the transplanting of in vitro-grown plantlets and the complete establishment in the greenhouse can be complex for some species (Van Huylenbroeck \& Debergh, 1996; Ross-Karsten et al., 1998).

The selection of a suitable substrate can be decisive for acclimatization. The low effectiveness of vermiculite as a substrate in the acclimatization of apple tree rootstocks and gloxinia plantlets demonstrates the importance of this parameter in this process (Hoffmann et al., 2001; Silva et al., 2003).

In view of these difficulties and of the absence of data regarding acclimatization of the genus Heliconia, the present work had the objective of evaluating the behavior of such plantlets on different substrates and under different shade levels in the acclimatization process.

\section{MATERIAL AND METHODS}

The experiment was carried out in a plant nurs-

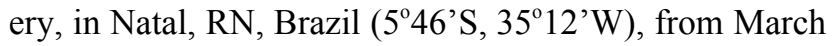
to August, 2002. The material consisted of micropropagated $H$. bihai plantlets (Lobster Claw I), obtained from shoot apices, which were at the twelfth in vitro subculture. Part of this material was rooted in a solid culture medium containing one half of the MS (Murashige \& Skoog, 1962) salts concentration and $6.0 \mathrm{~g} \mathrm{~L}^{-1}$ Agar with Morel vitamin (Morel \& Wetmore, 1951), $30.0 \mathrm{~g} \mathrm{~L}^{-1}$ sucrose, $0.1 \mathrm{mg} \mathrm{L}^{-1}$ indolebutyric acid (IBA), and the $\mathrm{pH}$ adjusted to 5.8 .

The assay was comprised of 2,520 plantlets with an average size of $7.0 \mathrm{~cm}$, which were planted in plastic trays with 24 cells each, containing different substrates: washed sand (autoclaved), Eucatex vermiculite (medium texture), and Eucatex PlantMax ${ }^{\circledR}$ Horticultura. Shade levels were evaluated with the use of shade cloth (sombrite), consisting of the union of $1.5 \mathrm{~m}$ wide screen pieces, with a randomic shading order: $0 \%$ (full sun), $40 \%, 50 \%, 80 \%, 70 \%, 30 \%$, and $60 \%$, arranged in the north-south direction to prevent the interference among treatments. The trays containing different types of substrates were arranged side by side for each shade level. The seven different shade levels with three substrates resulted in 21 treatments, each consisting of a plastic tray with 24 cells.

Irrigation was made through automatically-controlled fogging nozzles, installed every $1.0 \mathrm{~m}, 1.0 \mathrm{~m}$ above the trays, providing a relative humidity of $80 \%$, common to all treatments. The experimental design was organized as randomized blocks in a $3 \times 7$ factorial scheme (substrate $\times$ shading), and each treatment was repeated five times. Each replicate lasted 28 days, after which the live acclimatized plants were counted. The results thus obtained were evaluated through analysis of variance in a factorial scheme, and the substrate means were compared by the Tukey test. The degrees of free- dom corresponding to the shading factor were partitioned by polynomial regression $(\alpha=5 \%)$.

\section{RESULTS AND DISCUSSION}

The survival percentage of plants was affected by substrate and by shading level. The substrates used for acclimatization revealed that vermiculite has a low yield as compared to washed sand and PlantMax ${ }^{\circledR}$ Horticultura, at all shading levels. Inexpressive survival, ranging from $5.83 \%$ (30\% shade) to $32.50 \%$ ( $80 \%$ shade), indicate that the use of vermiculite should not be recommended for the acclimatization of this crop. In vermiculite, the dead heliconia seedlings did not present new roots, and their leaves were severely affected, showing rapid wilting of the leaf blade with later necrosis. The acclimatized seedlings that survived had at least one leaf in good condition, which contributed toward the emission of roots; preexisting roots, originated during the in vitro rooting, were not functional, without the emission of secondary roots, and presented root tissue necrosis. Vermiculite showed a low capacity of aggregation with the roots, which negatively affected plant development, in agreement with Hoffmann et al. (2001), who worked with apple tree rootstocks, and Silva et al. (2003), with gloxinia plantlets.

The substrates washed sand and PlantMax ${ }^{\circledR}$ Horticultura had similar yields, with expressive survival rates $(72.50 \%$ and $71.66 \%)$ beginning at $50 \%$ shade, reaching up to $95 \%$ and $93.33 \%$ respectively, at $80 \%$ shade. Survival was inexpressive below $50 \%$ shade, with rates lower than $27.50 \%$. The abnormalities caused by in vitro culturing, such as cuticle alterations, epicuticular wax, and lack of functionality of the stomatal apparatus, observed by Marin et al. (1988); Preece \& Sutter (1991); Desjardins (1995); and Pospísilová et al. (1999; 2000) could be the reason for the difficult acclimatization at shade levels below $50 \%$.

Shade levels of 70 and $80 \%$ had a survival rate stability for the substrates washed sand $(94.16 \%$ and $95.0 \%)$ and vermiculite (31.66\% and 32.5\%), and a slight decrease for the PlantMax ${ }^{\circledR}$ Horticultura $(95.0 \%$ and $93.3 \%$ ), which indicates that the maximum shading limit for this heliconia species is $80 \%$.

The acclimatized seedlings that survived presented emission of new roots and the same non-functional behavior, and root tissue necrosis of in vitro-induced roots. The non-functionality of the roots produced during the in vitro process suggests that this crop may become acclimatized without plantlets going through a rooting stage in the laboratory, which would eliminate one step in the micropropagation process. Plantmax ${ }^{\circledR}$ Horticultura provided good aggregation to roots and water retention, whereas sand had an excellent drainage with satisfactory aggregation to the roots. 


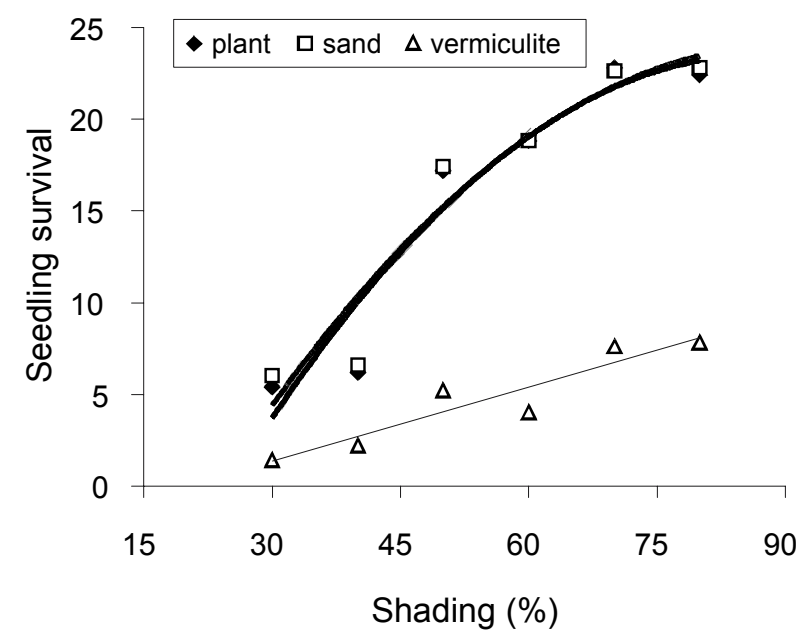

$\begin{array}{ll}\text { yPlantmax }=-22.6+1.06 x-0.006 x^{2} & R^{2}=0.92 \\ \text { ySand }=-19.9+0.97 x-0.005 x^{2} & R^{2}=0.92 \\ \text { yVermiculite }=-2.7+0.13 x & R^{2}=0.88\end{array}$

Figure 1 - Effect of shade levels and substrates on the survival of heliconia seedlings during acclimatization, 28 days of ex vitro culture.

Treatments followed by distinct letters are different by Tukey test. $(P<0.05)$.

Plant survival rate was zero for all substrates evaluated in the $0 \%$ shade treatment (full sun). Figure 1 presents the middle point distributions, their respective equations, and coefficients of determination $\left(\mathrm{R}^{2}\right)$ for the interval between 30 and $80 \%$ shade. For the substrates washed sand and Plantmax ${ }^{\circledR}$ Horticultura, plant survival increase was quadratic, with a linear increase for vermiculite. Increased levels of shading promoted a quadratic increase in the percentage of surviving plants during the acclimatization stage for Plantmax ${ }^{\circledR}$ Horticultura and Sand, and a linear increase for vermiculite.

\section{ACKNOWLEDGEMENTS} Inovação).

To BioCampo Ltda and CNPq (RHAE - Projeto

\section{REFERENCES}

ATEHORTUA, L. Heliconias: A new challenge for the Colombian floricultural industry. Biotechnology and Development Monitor, v.31, p.2021, 1997.

CASTRO, C.E.F. Helicônias para exportação: aspectos técnicos da produção. Brasília: EMBRAPA; MAARA; FRUPEX, 1995. 44p.
CASTRO, C.E.F.; GRAZIANO, T.T. Espécies do gênero Heliconia (Heliconiaceae) no Brasil. Revista Brasileira de Horticultura Ornamental, v.3, p.15-28, 1997.

DESJARDINS, Y. Photosynthesis in vitro - on the factors regulating $\mathrm{CO}_{2}$ assimilation in micropropagation systems. Acta Horticulturae, n.393, p.45-61, 1995.

DIAS, M.A.S. Determinação de fontes de explantes em Helicônia (Heliconia bihai, ANGIOSPERMAE, HELICONIACEAE), isolamento, identificação e controle de microrganismos envolvidos nas dificuldades de cultivo in vitro. Natal: UFRN, 2002. 86p. (Dissertação - Mestrado).

DIAS, M.A.S.; RODRIGUES, P.H.V. Fontes de explantes e contaminantes isolados em cultivo in vitro de Heliconia bihai (HELICONIACEAE). Revista Brasileira de Horticultura Ornamental, v.7, p.165-168, 2001.

HOFFMANN, A.; PASQUAL, M.; CHALFUN, N.N.J.; FRÁGUAS, C.B. Efeito de substratos na aclimatização de plantas micropropagadas do porta-enxerto de macieira 'MARUBAKAIDO'. Ciência Agrotecnológica, v.25, p.462-467, 2001.

MARÍN, J.A.; GELLA, R.; HERRERO, M. Stomatal structure and functioning as a response to environmental changes in acclimatized micropropagated Prunus cerasus L. Annals of Botany, v.62, p.663-670, 1988.

MOREL, G.; WETMORE, R.H. Tissue culture of monocotyledons. American Journal of Botany, v.38, p.138-140, 1951.

MURASHIGE, T.; SKOOG, F. A revised medium for rapid growth and bioassays with tobacco tissue cultures. Physiologia Plantarum, v.15, p.473-497, 1962.

POSPÍSILOVÁ, J.; TICHÁ, I.; KADLECEK, P.; HAISEL, D.; PLZÁKOVÁ, $\mathrm{S}$. Acclimatization of micropropagated plants to ex vitro conditions. Biologia Plantarum, v.42, p.481-497, 1999.

POSPÍSILOVÁ, J.; HAISEL, D.; SYNKOVA, H.; CATSKY, J.; WILHELMOVÁ, N.; PLZÁKOVÁ, S.; PROCHÁRKOVÁ, D.; SRÁMEK, F. Photosynthetic pigments and gas exchange during ex vitro acclimatization of tobacco plants as affected by $\mathrm{CO}_{2}$ supply and abscisic acid. Plant Cell, Tissue and Organ Culture, v.61, p.125-133, 2000.

PREECE, J.E.; SUTTER, E.J. Acclimatization of micropropagated plants to the greenhouse and field. In: DEBERGH, P.C.; ZIMMERMAN, R.H. (Ed.) Micropropagation, technology and application. London: Kluwer Academic, 1991. p.71-93.

ROSS-KARSTENS, G.S.; EBERT, G.; LUDDERS, P. Influence of in vitro growth conditions on stomatal density, index and aperture of grape, coffee and banana plantlets. Plant Tissue Culture and Biotechnology, v.4, p.21-27, 1998.

SCIUTTI, R.; MORINI, S. Effect of relative humidity in in vitro culture on some growth characteristics of a plum rootstock during shoot proliferation and rooting and on plantlet survival. Advances in Horticultural Science, v.7, p.153-156, 1993.

SILVA, A.B.; PASQUAL, M.; MACIEL, A.L.R.; DUTRA, L.F. BAP e substrato na aclimatização de plântulas de gloxínia (Sinningia speciosa Lood. Hiern.) provenientes de cultura de tecidos. Ciência Agrotecnológica, v.27, p.255-260, 2003.

VAN HUYLENBROECK, J.M.; DEBERGH, P.C. Physiological aspects in acclimatization of micropropagated plantlets. Plant Tissue Culture and Biotechnology, v.2, p.136-141, 1996.

$\overline{\text { Received April 23, }} 2004$

Accepted February 23, 2005 